\title{
COMMUNICATION AND PRAGMATIC ASPECT OF MODERN UKRAINIAN TEXT
}

\section{Nazarenko O. M.}

\section{INTRODUCTION}

The dominance of the anthropocentric approach in the linguistics of the XXI century determines the intensification of communicative and pragmatic researches, aimed at in-depth study of the role of the addressee and the sender in speech interaction. This aspect acquires a special role in the study of media activities mediated through the media, in particular print media, among which the maximum attention is drawn to newspaper texts given their inherent accessibility, prompt response to current events, which determines the specifics of their linguistic design.

In modern linguistics, scientists pay special attention to the communicative-pragmatic approach to the analysis of a newspaper text, because it allows the study of both its intratextual features and pragmatic guidelines of speakers, their communicative interaction, links with other texts in media and sphere of culture and literature, speech influence on the addressee, which in general is the basis of the category of dialogicity as an essential feature of the newspaper text and determines the relevance of scientific research. Dialogicity as a category of newspaper text is expressed through the main components of the communicative act - the participants of communication and text message.

Two communicators take part in the communicative act, O. Selivanova considers the communicator the most important component of the communicative situation and defines it as "a person, the subject of a communicative act that transmits information or communicative influence or perceives and interprets them"1. Subjects of speech and perception are the main components of communicative interaction, which are related to the pragmatic aspect of the study of verbal communication and text. Pragmalinguistic study of the text is primarily focused, on the one hand, "to identify the features of the author's presence", , and on the other - to the recipient. Linguists distinguish two communicators according to the main

\footnotetext{
${ }^{1}$ Селіванова О.О. Основи теорії мовної комунікації. Черкаси, 2011. С. 100.

${ }^{2}$ Седов К.Ф. Дискурс и личность: Эволюция коммуникативной компетенции. Москва, 2004. С. 30.
} 
functions they perform in the communicative act - the sender and the addressee. The sender is a communicator, he is a speaker or author of the text, he is considered an active participant in the communicative act, because it is the sender who initiates communication and regulates its subject matter and pragmatic content, the intentionality of communicative interaction is set by the sender.

\section{The addressee factor in the representation of the text category of dialogism}

The sender initiates the communication, generates the text, sends the message to the interlocutor - the addressee. Communicative subject-objectsubject interaction of both participants generates a category of interactivity, which O. Selivanova defines as text-discursive, the linguistic basis of which is "speech system, the purpose of which is realized communication" 3 . The sender factor is directly related to subjective modality, which is "layered on the basic modal qualification" and "creates additional modal interpretation of utterances" $"$, subjective modality can be realized with the help of various lexical (insert words, modal particles, exclamations) and non-lexical (intonation, word order or special syntactic constructions). Subjective modality is interpreted as "an optional semantic-pragmatic factor of the communicative situation and communication in general, which is realized as a number of different relations of the sender (speaker, author) to the reported", the source of which is "evaluation, its subject is the speaker, object - various aspects of the relation of the content of communicative units to reality, by means - language units, categories..." . Subjective modality is expressed in the text by different linguistic means, but all of them are conditioned by the realization of the sender factor, e.g.: У Себастьяна Жапрізо є чудовий роман, що так $i$ називається - «Убивче літо» (багато хто пам'ятає екранізацію з Ізабель Аджсані в головній ролі). Звісно, ие не якийсь там курортний детектив, а дуже серйозна психологічна книжка... Чию назву й запозичимо для невеличкого "ревю»: яке «відпускне кіно» варто подивитися $і$ яке иікаве чтиво допоможе скоротати «убивче» (через спеку й дощі) літо? (Дзеркало тижня. №27.2011). In this fragment, subjective modality is expressed not only by explicated markers of the sender factor, but also by the

3 Селиванова Е.А. Основы лингвистической теории текста и коммуникации. Монографическое учебное пособие. Киев, 2002. С. 234.

\footnotetext{
2000. C. 338

5 Бацевич Ф.С. Нариси 3 лінгвістичної прагматики. Монографія. Львів,
}

Вихованець I.P. Модальність. Українська мова. Енциклопедія. Київ, 2010. C. 191. 
corresponding syntactic constructions that convey subjective-modal meanings.

The sender forms the subjective-modal semantics of the text as a result of communicative interaction. F. Batsevych determines the types of modal semantic-pragmatic meanings that the speaker forms within the framework of communicative interaction:

1. The speaker's expression of the assessment from the standpoint of reality / unreality of what is said in the text.

2. Assessment from the standpoint of the possibility, necessity or desirability of what is said in the message.

3. Assessment of the degree of confidence of the addressee in the accuracy of what is said.

4. The target setting of the author of the message, according to which narrative, interrogative and optative sentences are distinguished.

5. The value of a statement / objection to the existence of objective connections, signs, events, etc.

6. Subjective and communicative negation can be considered as purely linguistic types of modality ${ }^{6}$.

The sender is considered the initiator of communication, and in the case of written communication - the main subject of the communicative act, which determines the direction of communication, produces speech, addresses it to the interlocutor.

Linguists distinguish between different types of senders: O. Selivanova distinguishes the following types of senders in the text: collective sender two authors of the text or a team of authors; unknown sender - due to the temporal remoteness of the modes of generation and interpretation; irrelevant sender - discursive location is limited by the author-function and does not require a specific author's update; generalized sender - the authorfunction correlates with the collective carrier of ethnic consciousness.

The peculiarities of the sender in the newspaper text should be noted: according to $\mathrm{T}$. Vinokur, journalistic speech is an example of "quasiindividual content of the speech act as the action of one person"7. This means that the sender of a newspaper text does not always express his own point of view, the subject of broadcasting is a publication, the information policy of which mostly coincides with the author's position.

6 Бацевич Ф.С. Нариси 3 лінгвістичної прагматики. Монографія. Львів, 2010. C. 192.

7 Винокур Т.Г. Говорящий и слушающий. Варианты речевого поведения. Москва, 1993. С. 52. 
In the newspaper text the factor of the sender is first of all actualized through the author's position which can be expressed explicitly, e.g.: Прочитавщи в «Новій газеті» статтю Ю. Латиніної «Як насправді влаштована сучасна Росія», не зміг утриматися від української аналогії. Для чистоти експерименту довелося скористатися авторською - Юлії Леонідівни - матрицею. На жаль, мої спроби зв'язатися з пані Ю. Латиніною щодо авторських прав через редакиію газети, в якій вийшла публікація, не мали успіху... (День № 21.2011). The author of the cited material acts as an active sender, emphasizing not only his position of linguistic personality, but also describing certain actions that preceded the creation of the material, both the existing speaker and the figure in one person of the author. Under such conditions, the author's point of view dominates in the text, respectively, and used grammatical means of its representation: verb forms, pronouns, modal constructions that manifest the addressee. Moreover, the author performs two functions at the same time the speaker and the recipient (reader), because it indicates that his publication was the result of reading the newspaper material of another author, emphasizes the close connection between perception and production of newspaper text. Such a message is maximally individualized, it expresses the author's point of view and is addressed.

Explication of the position of the sender in the newspaper text is often accompanied by an increase in the internal dialogicity of the text, when the author points to a close relationship with the text addressee, e.g.: «T $\boldsymbol{T}$ почусш зовсім іншого, нового президента!» - змовницьки підморгуючи, по секрету повідомив мені знайомий нардеп-регіонал у четвер враниі, напередодні виступу Януковича в парламенті... (Дзеркало тижня № 13.2011). Quoting from a conversation with the addressee enhances the dialogic nature of the text, in which an indication of the close relationship between the author and the addressee is an appeal to "you", which involves informal communication. The reader feels that the author of the material is so familiar with the in-text addressee that this information was obtained directly, "first hand", so it is more likely than official reports or author's opinions or assumptions.

In the given examples the actualized intertextual dialogicity in the plane author - internal addressee, thus the addressee, is the real interlocutor of the journalist, but at the same time he becomes the internal textual communicator because conversation with him is reproduced in indirect form, ie indirectly in the text. This is best expressed in an interview. The degree of closeness of communicators is expressed through the explication of the addressee's factor, through the demonstration of the author's position. The real reader of a newspaper text only observes the communicative interaction between the author and his interlocutors, capturing the explication of the 
addressee's factor as the presence in the text of the author's position and subjective view of events.

In general, the newspaper text is not characterized by the dominance of the sender factor, in particular when it comes to informational messages. However, analytical materials or artistic and journalistic genres are not devoid of explication of the author's position and subjective point of view. Such an explication can be a sign of individual authorial style, as in the journalistic materials of the famous Ukrainian journalist Mykola Veresen, who creates texts on a dialogical basis, e.g.: "Секундочку, - запитаєте ви в мене, - а до чого тут наш Чорнобиль $і$ наме, що стало звичним за останні майже двадиять років, держпідприємство Чорнобильська атомна електростанція?" Відповім: $i$ в них, в Індонезії, $\epsilon$ зона постійної сейсмічної небезпеки, яка призвела до біди... Але найголовніше, відповім я вам, це те, що і там, в Індонезії, $і$ тут, в Украйні, реальна причина минулих $i$, можливо, майбутніх (не дай Боже) екологічних і техногенних бід - та ж сама: бездумність, байдужість, безсовісність і жадібність (Високий замок. 04.05.2005). In the fragment of the text the actualized communicative interaction represents communication of the author with the imaginary reader, instead of the internal interlocutor. The author simulates the image of the reader, constantly addresses him, choosing the appropriate language forms, asks questions on behalf of readers and immediately answers them. The text is created as an imaginary dialogue with a potential reader in the form of alternate questions and answers, so it resembles the usual spontaneous communication, the difference of which is the programmability of the questions. The author formulates the questions in this way to reveal the main problems that, in his opinion, should be of interest to readers.

The sender of a newspaper text does not have such a multilevel typology as, for example, in an artistic text, where it is represented by the author, lyrical hero and intratextual addressee ${ }^{8}$, but in the newspaper text he is more clearly expressed and explicated. The textual subject expresses the author's position, it does not "break down" into images of characters, narrators, etc., but is a holistic subject of speech, which participates in communicative interaction with both the real reader and the intertextual interlocutor.

In a newspaper text, the sender as a subject of broadcasting does not always appear in the same person, identified with the author of the journalistic material, when the text presents the author's position, outstanding view, and the author comments and evaluates the described events on his own behalf. The factor of the sender can be expressed in

\footnotetext{
${ }^{8}$ Новиков А.И. Семантика текста и его формализация. Москва, 1983. С. 10.
} 
general, with the help of grammatical forms of the first person plural of the verb and the corresponding pronoun forms - we, ours. In this case, we have a collective sender, which unites different people together with the direct author of the journalistic text, the author acts not only on his own behalf, but also on behalf of his associates, accomplices, friends, etc., so the sender becomes generalized. The most common variants of such an association, in our opinion, are two: first, it is a generalized sender - the author and intratextual subjects, and secondly, it is an association of the author with the reader, the sender allegedly acts not only as a subject of speech, but also as the addressee, it focuses on the position of the reader.

An internal generalized addressee involves the merging of several subjects, among which the author dominates, e.g.: Колись, багато років тому, нас, кількох журналістів-початківців, запросили на відкриття виставки дитячого малюнка (Дзеркало тижня № 10.2011). The author narrates the events on his own behalf, but the intratextual subjects in this fragment are not one person, but a group of people, so the speaker avoids subjective assessments and presents information in general. This type of sender is due to the desire to distance oneself from the described events, the author emphasizes the polysubjectivity of the situation, although he describes it. First of all, this type of addressee is found in texts where the author is one of the active members of a certain group of people, and therefore emphasizes the collectivity of the described actions.

A more frequent typical general addressee is the association of the author with the reader address, the latter can be manifested in different ways in the text, primarily by means of purely grammatical means, e.g.: $У$ світлий день - а ие 27 березня - досить нам скімлити чи зі скорбною міною нарікати по закутках: "нікому ставити! ", «наш театр схожий на труп!», «усі, хто був, або померли, або виїхали...» Так ми далеко не заїдемо! I вже ж точно поважати себе не примусимо (Дзеркало тижня № 11.2011). The generalization of the author and the reader does not occur as an artificial combination of the subject of speech (journalist, author) and the real or potential reader, but as the positioning of the author as one of the ordinary readers, as the same subject as all recipients. The author does not oppose himself to the readers even in the communicative act, but emphasizes the identity of the communicative positions of the addressee and the addressee as participants in the communicative act.

In this case, the pronoun "we" indicates the author's identification with potential readers and outlines the range of subjects that are generalized in the text, e.g.: Чи є нам, україниям, діло до того, щьо відбувалося нещодавно на Всесвітньому економічному форумі в Давосі? Без сумніву, бо міць нашої національної валюти трунтується не лише на вітчизняних 
підприємствах, а й на світових ринках (Сільські вісті № 12.2011). The speaker unites himself and potential readers as speaking on behalf of the generalized sender. The author simultaneously acts in an active communicative position, appealing to the recipients, and at the same time expresses himself as a collective sender, moves to the recipients of the message, he to some extent combines the functions of the sender and the addressee. This technique is focused on the dialogic nature of the newspaper text, because the sender, producing speech, first of all actualizes the factor of the addressee.

The addressee may not be mentioned in the text, but only presented in general terms with the author, i.e the speaker does not separate himself from the readers, but unites himself with them, e.g.: Можнливо, це збіг обставин, можсливо, закономірність. Але факт - кепкування польських парламентаріїв щодо «багатоверстатного» голосування наших нардепів стимулювало їх «заворушитися» (День № 41.2011). In this text fragment the sender's factor is expressed by means of subjective-modal means - insert words of modal semantics, and the phrase "our people's deputies" indicates political subjects, i.e transfers semantics of association on parameter of political character: all citizens of the country have one People's Deputies, so they are the recipients of this newspaper report. The author also belongs to the Ukrainian citizens, therefore he emphasizes his commonality with readers, the described problems concern him directly. However, the chosen plural form creates the effect of dialogicity and indicates the indifference of the speaker to the described situation.

In general, the use of first-person plural pronouns and corresponding verb forms is one of the ways to represent intratextual dialogicity, given that the author considers the addressee factor as the main in the text, combines himself with the addressee, focuses on the "expectation horizon" and generalizes himself with the addressee. The author-sender of the newspaper text cannot but focus on the factor of the addressee, because the latter determines the relevance and significance of newspaper materials. The peculiarity of the sender of a newspaper text is that it coincides with the real author of journalistic material, who is both an in-text subject of speech and an out-of-text subject - a real author. The sender may have different ways of representation in the text - from the explication of the position of the subject of speech to the generalization with the recipients, but he is a holistic communicator, not represented by different text senders. 


\section{The addressee factor in the expression of the text category of dialogism}

The factor of addressing the text linguists interpret as "the desire of the speaker to adequately understand the addressee of the speech work" ${ }^{\text {. }}$. The addressee's position, at first glance, seems secondary to the sender, because he perceives the speech generated by the sender, interpreting the content. According to O.O. Selivanova, the addressee is "one of the communicators to whom the speech action of the person who generates the statement is directed and calculated, ie the interlocutor or the reader, the recipient of the message" ${ }^{10}$. Recently, however, the position of the addressee is considered as active as the position of the sender, due to the ability of the addressee not only to recognize the intentions of the speaker, but also to add new semantics to the message.

If the addressee in the newspaper text, in contrast to the literary text, does not have a detailed typology, the addressees are represented by several varieties.

O.P. Vorobyova, analyzing artistic communication, identifies the following types of recipients: real (empirical) reader; imaginary, potential reader that embodies the model of the ideal reader according to a particular text; the text reader combines the image of the ideal reader and the image of the fictitious reader ${ }^{11}$.

In a newspaper text, we distinguish between two main types of recipients - the real reader, which the author focuses on in creating the text, and the in-text recipient, who acts as the interlocutor of the author in the text (in the interview). In our opinion, the appeal to the reader in the text involves the explication of a real non-text reader, to which the author appeals. Each author of a newspaper text has his own idea of the ideal reader, but the relevance and efficiency of newspaper messages require a focus on the real reader, rather than modeling the ideal recipient ${ }^{12}$.

The complexity and multi-layered nature of the addressee of a newspaper text is determined by the specifics of mass communication. In mass media research, to which a newspaper text belongs, the addressee is called a mass addressee, and "finding common ground with a mass addressee means showing a willingness to use a standard designed to achieve goals that unite certain types

${ }^{9}$ Седов К.Ф. Дискурс и личность: Эволюция коммуникативной компетенции. Москва, 2004. С. 31.

${ }^{10}$ Селіванова О.О. Основи теорії мовної комунікації. Черкаси, 2011. С. 16.

${ }^{11}$ Воробьева О.П. Текстовые категории и фактор адресата. Монография. Киев, 1993. C. 106.

12 Назаренко О.М. Реалізація категорії діалогічності в сучасному українському газетному тексті. Автореф. дис. канд. філол. Одеса, 2012. С. 6-7. 
of socially significant speech spheres"13. Such a mass addressee provides a generalized, collective, collective view of the recipient of the message, given that it is difficult to predict the reaction of the addressee to the text.

In a newspaper text, a direct appeal to readers is frequent, which enhances the intratextual dialogicity, e.g.: Сумно виходить, друзі мої... Іншими словами, читачу, забувають й ігнорують усім відомі факти, «що випали» $з$ мотиваиій поводження тих, хто зобов'язаний вирішувати проблеми ядерної безпеки (Високий замок 04.05.2005). In this passage the factor of the addressee has an explicit expression - by means of the address and use of an vocative case the author appeals directly to readers. In addition, there is a coincidence of the in-text addressee and the real reader, so the author addresses the readers of his material, noting them in the text. In this case, textual communication is fully represented: the author simulates a dialogue with the reader in the text, so the text is built as a conversation, it contains some extended remarks of the speaker addressed to the addressee, the author's reasoning and appeal to the interlocutor. This technique is used not only in newspaper articles, but is generally characteristic of mass and artistic communication.

Modeling a conversation with an imaginary or potential reader involves the explication of the dialogic nature of the text, the addressee focuses on the "expectation horizon" of the recipient, which is emphasized by the dialogic form of the text.

Dialogue with the reader in a newspaper text further intimates such communicative interaction, given that it is no longer so much a conversation with a mass audience as with each reader individually. In view of this, the dialogue is created as a face-to-face conversation between the author and the reader, e.g.: Це дуже політичне питання для країни ци дуже філософське. Якщо в дитинстві ти розбив шибку, то чи маєш ти, читачу, право зробити щось шляхетне подорослішавши, скажімо, перевести бабусю через дорогу? Багато хто вважає, що не маєш. I дуже мало хто вважає навпаки... I тут я, перепрошую, дорогий читачу, подумав, щзо відповіді на запитання: чому в усьому винна саме Юлія Тимошенко - у природі не існує (Дзеркало тижня № 4.2011). The addressee expresses and evaluates the events as subjectively as possible, modeling the dialogic interaction with the reader. Through the use of the second person singular form, the dialogue is perceived as a conversation between close people, which does not require additional forms of politeness. In a newspaper text, readers are addressed only in two ways: either to a mass

13 Винокур Т.Г. Говорящий и слушающий. Варианты речевого поведения. Москва, 1993. С. 63. 
addressee or a generalized audience using the plural form and the corresponding verb forms of the 2nd person plural, or to an imaginary specific reader using the singular form. The authors do not use 2 nd person forms for you, which provide a polite attitude and are typical for communication with strangers. This means that an imaginary reader in a newspaper text is always a close, familiar person, a communicator; with whom you can discuss almost all problems; it is an indifferent addressee who shares the author's opinions.

The focus on the addressee factor is always implicit in the text, even if there are no linguistic forms of expression of the reader or appeal to the reader.

The newspaper text is designed to communicate current information or present an argumentative analysis of events, with the addressee factor always dominating: the information should be of interest to readers, even if the author does not consider it so.

Mass communication, in our opinion, is characterized by the dominance of the addressee factor, which determines both the content and the way of presenting information. This orientation towards the reader finds its expression in the constant appeal to the collective reader in the text, e.g.: $Я$ розумію, щчо більшість читачів, прочитавщи ці рядки, подумали щось на зразок: "Ну скільки ж можна? Навіщьо стільки писати про одне й те ж». Цих читачів хочу відразу заспокоїти: ией лист не про гроші $і$ Європу, він про Руслану $і$ Украйну (Високий замок № 127.2011). In this passage, the author tries to predict the reaction of readers, the analysis of the "horizon of expectation", implicitly entering into a dialogue with potential recipients. In this case, on the one hand, readers in the text become internal subjects, and on the other hand, remain outside the text. The linguistic means of expression of the addressee factor here are the corresponding grammatical forms of the plural, which allow the generalization of textual recipients.

The focus on the mass reader in newspaper publications takes a specific form: the authors often address or appeal not to readers in general, but specifically to the readers of the specific newspaper, e.g.: "Високий Замок» продовжус знайомити читачів із «сімейною кухнею» політиків, які не почуваються обділеними через один штамп у паспорті (Високий замок № 127.2011). The sender is also a generalized subject - the newspaper's editorial office, although the author of the material is a specific journalist, whose name appears in the material. The restriction of readers of one edition indicates the exclusivity of these recipients: the information becomes exclusive, because it is provided to the readers of a particular publication, and not to the mass recipient. Concretizing the readership, even in such a way as "our readers", emphasizes the unique status of the real recipients of the newspaper message, which separates them from potential readers. The 
authors allegedly appeal to real readers, to a "permanent", "loyal" audience, emphasizing their attitude to the recipients and encouraging the latter to further communicative interactions.

The addressees in the newspaper text, which can be both real readers and in-text subjects, have specific linguistic means of expression, among which the main role is played by appeals, motivating and interrogative syntactic constructions.

The address directly indicates the addressee of the speech, indicating it in the text, it is "intonationally removed component of the sentence, which names the beings to whom the speech is addressed"14. In the Ukrainian language, the address has a special grammatical way of expression - the vocative case - and is most often used in persuasive syntactic constructions and interrogative sentences of direct interrogation.

In a newspaper text, appeals can be used both in the headlines and in the main text. In the titles, they mainly perform a rhetorical function, functioning in an unusual form - in narrative exclamatory sentences, where the emotional component is clearly expressed, e.g.: Соррі, бабусю! Але вам - у іниий заклад! (Київська правда №9.2011); Украӥно, я люблю тебе! (День № 177-178. 2010); “Нарешті я знайшов тебе, Степане!» (День № 222-223. 2010); Вітаємо тебе, Естоніс! (День № 4-5.2011); Пам'ятаємо тебе, Назарію! (Украӥнське слово № 48.2010); Ой, мамо... (Сіверщина 22.01.2011); Довго живете, бабусі! (Чорноморські новини № 11.2011). The presence of emotional appeal in the title complex emphasizes the dialogic nature of the text, it is a dialogue between the sender and intratextual addressees, named in the appeal, but the rhetorical nature of such syntactic constructions mostly indicates a conditional dialogue not realized in the main text.

The titles also use poetic appeals, represented by quotations from the works of Ukrainian and foreign writers, given in quotation marks, e.g.: «Південний краю! Стороно прекрасна!»: 25 лютого минає 140 років від дня народження Лесі Украӥнки (Кримська світлиия № 4. 2011); «Я для тебе горів, украӥнський народе...» 75 років від дня народження Василя Симоненка (Кримська світлиия № 2. 2010). Dialogism in such headings is of a dual nature: on the one hand, the citation indicates an intertextual interaction, and on the other hand, the presence of an appeal in the headings represents intratextual dialogicity.

In headings, appeals are often used in motivational syntactic constructions represented by motivational sentences, e.g.: Почуй, владо!.. (День № 202-203. 2010); Ловись, рибко, легально (День № 211.2010);

${ }^{14}$ Вихованець І.Р. Звертання. Українська мова. Енциклопедія. Київ, 2000. С. 184. 
Водись, рибко, велика і маленька... (Київська правда № 5. 2011); Здрастуй, владо, я - твій соиіальний тероризм? (Украӥнське слово № 3. 2011); Українці, обираймо українську владу! (Украӥнське слово № 42.2010); Божее, нам єдність подай! (Украӥнське слово № 40.2010); Краӥно, не пропусти розмову з собою (Кримська світлиия № 4. 2011); Щедруйте, люди! (Сіверщиина 8.01.2011); Почуйте його, люди... (Сільські вісті № 20.2011); Дзвени, дзвени, моя бандуро! (Кримська світлиия № 2.2011); Грай, бандуро, грай! (Кримська світлиия № 43.2010); Украйнці, не дайте себе купити! (Кримська світлиия № 2.2010); Тож здрастуй, Білий Кролику! (Чорноморські новини № 10.2011) або їхніми еквівалентами, напр.: Для тебе, тату: Вийшла друком книжка доньки Івана Франка (День № 207-208. 2010); Браво, капітане! Українські моряки не здались піратам! (Сіверщина 30.11.2010); Руку, друже! (Сільські вісті № 19.2011). The real addressee in this case remains the reader, and in the address the addressee does not always point to the internal subjects of speech, although he outlines their thematic range. Generalized addressees appeal to the real addressee-reader, and other appeals mostly manifest the rhetoric of the headlines, but do not encourage the action of the subjects mentioned in the headlines, in particular, this applies to personalized appeals when the author appeals to non-beings. Appeals to beings are also predominantly of the rhetorical type, е.g.: Корупціонери, тремтіть! (Сіверщина 3.12.2010); Гуртуймося, РУНВірівці! (Чорноморські новини № 11.2011); Святкуй, студенте! (КП. № 7.2011); Прощавайте, Борисе Миколайовичу (Сільські вісті № 17.2011). Such headlines with appeals and motivations express the category of dialogicity in full, even if there are no explicit markers of dialogicity in the main text of the newspaper material.

The motivation in the title complexes does not necessarily contain an appeal, it can be represented by personal sentences addressed to readers, e.g.: Врятуй свою мову! (Украӥнське слово № 40.2010); Готуй потяг влітку! (День № 196. 2010); Кожний знай, щяо на тобі мільйонів стан стоїть (Украӥнське слово № 43.2010); Плекаймо соборність ділами! (Кримська світлиия № 1.2011). Motivational syntactic constructions in the headings also explain the addressee's factor, although they do not point to it directly as sentences with appeals, which is why they are perceived as addressed directly to the mass addressee. The author in such titles appeals to readers, encourages them to action, creates the effect of dialogic interaction with potential readers.

In the main text of newspaper materials, appeals and persuasions are used to a lesser extent if the text is not built on a dialogical principle. However, the presence of the appeal emphasizes the implicit, indirect dialogic nature of the newspaper text, in which the author's monologue is 
addressed to a specific audience named in the appeal, e.g.: Головне, дядечки і тітоньки, - серием не старіти. А про те, щоб ми якнайдовще не втрачали фізичних кондицій і працездатності, «подбав» уряд (Дзеркало тижня № 48.2010). The address indicates the real addressee of the text - the mass addressee-reader, whose name may be different. An appeal to a mass addressee is available in the text in an explicit or implicit form, and the appeal indirectly enables its explication. The author may use in the address of the token reader, readers or others that point to the imaginary reader and generalize the readership.

Another type of addressee - in-text - is presented in the newspaper text by appeals to the author's interlocutors. Such an addressee is relevant only for dialogically constructed texts, when the author-journalist talks to the addressee - a famous person, and their conversation is socially significant and interesting for readers: Постановку вистави за мотивами твору «Мефістофель» Бойто здійснила молодий київський режисер Лариса Леванова. Вона належить до так званого покоління нульових: гнучкого, енергійного та надзвичайно мобільного. I разом з тим - у найкращсому смислі иього слова консервативного.

- Ларисо, наскільки реалізація задуму вистави «Фауст. Відображення» виявилася близькою до початкової вашої ідеї?

- Із Музеєм Булгакова я співпрачюю вже доволі давно, у иьому будинку ставила свій перший спектакль - «Орфей та Еврідіка» Глюка (День № 88.2011).

An excerpt from the text of the interview is given, in which the appeal is used in the author's remark-question addressed to the interlocutor of the journalist. However, in a newspaper text such cases are not frequent, because the questions in the interview are mostly generalized, they rarely indicate the name or patronymic of the interlocutor, but in a real conversation, which is reproduced by a newspaper interview, such appeals are mandatory, they are provided by the rules of etiquette.

In a newspaper article, a complete repetition of a real conversation would be semantically excessive and unjustified, because the communicative situation of the interview already sets the dialogic type of text and does not require constant reminders.

The presence of treatment in the monologue of the author actualizes the factor of the addressee as an intratextual subject of speech, mostly of a rhetorical nature. The most striking illustration of such an appeal is the 
appeal to the "addressee" 15 , which is traditional for the text of the prayer, е.g.: Царю небесний, не карай Украйну! Не карай украӥнців горезвісними президентами. Украӥнський народ $є$ добрий, щзирий, розумний, талановитий, працелюбний, любить бути господарем на своїи землі у своїи державі. За що ж його карати? Дорогі украӥнці, громадяни Украӥни - не карайте самі себе! (Сіверщина 28.01.2011). The stylization of prayer in this fragment of the newspaper text presupposes the use of recourse to God with persuasive sentences with a pragmatic meaning of request. The author simultaneously appeals to the addressee and to his compatriots-readers, realizing the category of dialogism both as internal text and as external text, appealing to the addressees of different communicative spaces.

However, the main form of representation of internal dialogicity in a newspaper text is interrogative, which can be realized in two ways monological and dialogical.

In monologue speech, both questions and answers are produced by the author, who independently asks questions and answers them, e.g.: УХХІ столітті ми підхопили хворобу «неочинізму», про яку попереджала Ліна Костенко на початку 90-х. Нові прибічники демократичного псевдокультурного, порнократичного тоталітаризму? Чому в постмодерний час з'являються хай плюгавенькі, але інквізитори? Чому в постпостмодерний час можлива інквізиція? Може, від нестачі справжсньої Украйни модерної? Хто ми після цього? Народ чи чернь? (Дзеркало тижня № 5.2011). A number of interrogative sentences in the text provoke the author and readers to think, and the following text contains the author's attempt to answer these problematic questions. The sender simultaneously addresses these questions to himself and the readers, he actualizes the category of dialogicity in the text, emphasizing the communicative situation of dialogic interaction between the sender (author) and the addressee (readers).

There are no traditional dialogic units in this text, in which each question is answered, and each subsequent semantic block is determined by the previous one, because several similar questions have one answer, but it is represented by the whole text.

However, monologue speech can be constructed as a set of interrogativeaffirmative blocks, eg.: На екрани батьківщини вийшов антирязановський і трохи художній фільм «Службовий роман. Наш

${ }^{15}$ Бахтін М.М. Проблема тексту в лінгвістиці, філології та інших гуманітарних науках. Антологія світової літературно-критичної думки XX століття. [За ред. М. Зубрицької; 2-е вид.]. Львів, 2002. С. 306. 
час». Навіщо він вийшов? Щоб із допомогою перекупленого «лейбл» зразка 1978-го вже сьогодні «немножко денег срубить». Хто знімав? 26-річний юнак на прізвище Андреасян, який, кажуть, має за плечима «хорошу лондонську школу режисерської майстерності». Хто знімався? Завсідники російських $і$ украӥнських поп-шоу (Дзеркало тижня № 10.2011). The author asks specific questions, to which he answers, while giving the text a traditional dialogic form, ie questions are not rhetorical in nature, they need answers. The information available in the text could be represented in another way, without using dialogic units, but this method activates the factor of the addressee, emphasizing the internal dialogicity of the text.

Dialogic organization of a newspaper text mostly involves the use of interrogative sentences that require answers. In our opinion, this is the main form of representation of in-text dialogicity, so we will consider it in more detail.

\section{CONCLUSIONS}

The communicative-pragmatic aspect of the modern Ukrainian newspaper text is realized through the subject-text interaction, which involves a dialogue between the sender and the addressee, not directly, but through the text.

Dialogism as a category of newspaper text is expressed through the main components of the communicative act - the participants of communication and text message. Newspaper text is the interaction of two communicators the sender and the addressee, which have specifics due to the nature of mass communication.

The sender initiates a communicative act, produces speech, influences the interlocutor, in the newspaper text the sender is the author of journalistic material. The sender factor is directly related to the category of subjective modality, so it can be expressed through the syntactic constructions of modal semantics, in particular the inserted and inserted components of the sentence.

The sender in the newspaper text is integral, it does not consist of different aspects, but is identified with the only subject of speech - the author. The author can act individually and generalized, in the second case the generalization is realized as the union of the sender with different types of addressees - in-text (interlocutors of the author in the text) or out-of-text (readers). Linguistic means of expressing the factor of the sender are pronouns of the 1 st person singular and plural and the corresponding verb forms.

The addressee in the newspaper text is defined by the specifics of communicative interaction as mass, so it provides a generalized idea of the recipient-reader. Addressees are divided into internal - interlocutors of the author of the text, and external - readers. 
Linguistic means of expressing the factor of the addressee are appeals, motivational and interrogative sentences, grammatical forms of pronouns and verbs of the 2nd person singular and plural. Newspaper text is always targeted at the addressee, even if the latter is not explicitly presented and there are no means of its manifestation.

\section{SUMMARY}

The main attention of the author is paid to the analysis of the modern Ukrainian newspaper text in the communicative-pragmatic aspect. In this aspect, the peculiarities of the representation of the factors of the sender and the addressee are analyzed. It is established that the sender in a newspaper text can be expressed in general, verb plural forms and indicate generalizations of two types: 1) sender - author and in-text subjects, 2) sender - author and reader, which emphasizes the identity of communicative positions of addressee and addressee.

The generalized sender represents the in-text dialogism, unites and generalizes itself with the addressee. It is proved that in a newspaper text they address either a mass addressee or a generalized audience with the help of the plural form and the corresponding verb forms of the 2 nd person plural, or an imaginary specific reader with the help of the singular form. The factor of the addressee in the newspaper text which is expressed by means of addresses, motivating and interrogative syntactic constructions is analyzed. The in-text addressee is represented by appeals to the author's interlocutors and is relevant for dialogically constructed texts.

\section{REFERENCES}

1. Селіванова О.О. Основи теорії мовної комунікації. Черкаси, 2011. С. 100.

2. Седов К.Ф. Дискурс и личность: Эволюция коммуникативной компетенции. Москва, 2004. С. 30.

3. Селиванова Е.А. Основы лингвистической теории текста и коммуникации. Монографическое учебное пособие. Київ, 2002. С. 234.

4. Вихованець I. Р. Модальність. Українська мова. Енциклопедія. Київ, 2000. С. 338.

5. Бацевич Ф.С. Нариси 3 лінгвістичної прагматики. Монографія. Львів, 2010. С. 191.

6. Винокур Т.Г. Говорящий и слушающий. Варианты речевого поведения. Москва, 1993. С. 52.

7. Новиков А.И. Семантика текста и его формализация. Москва, 1983. C. 10.

8. Воробьева О.П. Текстовые категории и фактор адресата. Монография. Киев, 1993. С. 106. 
9. Назаренко О.М. Реалізація категорії діалогічності в сучасному українському газетному тексті. Автореф. дис. канд. філол. Одеса, 2012. C. 6-7.

10. Вихованець I.P. Звертання. Українська мова. Енциклопедія. Київ, 2000. С. 184.

11. Бахтін М.М. Проблема тексту в лінгвістиці, філології та інших гуманітарних науках. Антологія світової літературно-критичної думки ХХ століття. За ред. М. Зубрицької; 2-е вид. Львів, 2002. С. 306.

\section{Information about the author:} Nazarenko O. M., Candidate of Philological Sciences, Associate Professor at the Department of Applied Linguistics National University "Odesa Law Academy" 23, Fontanska doroha, str., Odesa, 65009, Ukraine 